DOI: $10.17951 /$ en.2018.3.225-240

\begin{tabular}{cc}
\hline & ANNALES \\
& UNIVERSITATIS MARIAE CURIE-SKŁODOWSKA \\
VOL. III & LUBLIN - POLONIA \\
\hline
\end{tabular}

\author{
Marzena Marczewska \\ Uniwersytet Jana Kochanowskiego w Kielcach \\ ORCID: https://orcid.org/0000-0002-2796-1317 \\ marzenamar@onet.pl
}

\title{
Man and Illness: A Picture of Fight Recorded in the Word
}

\author{
Człowiek i choroba: walka utrwalona w słowie
}

\begin{abstract}
Summary: In the article, the author discusses the relationship that refers to people and illness that is recorded in various language data. Based on folk material, the author recalls, above all, folk magic formulas, called "orders". The magical healing ritual is perceived as a whole, in which the word accompanies certain activities taking place at a given time and place, using specific attributes. In a very specific existential situation, which is illness, the most basic mechanisms of thinking about the reality are revealed. Hence, the healing ritual reveals perceptions and judgements referring to illness, based on one's own body experiences. These judgements can be observed through specific materialization obtained through the language/text manifested in a specific executive situation. The analysis of linguistic/text data allows one to discover the significance of performed actions in the process of magical healing, as these actions complement the word. They are also strongly associated with beliefs about illness in general and they constitute a characteristic testimony of human struggle with illness.
\end{abstract}

Keywords: ethnolinguistics; language image of the world; healing ritual; magic 


\section{INTRODUCTION}

The present article discusses a relation, deeply rooted in a variety of linguistic data, which concerns man and illness, whereby concentrating on one of the many aspects of such a relation, namely the man's fight against illness ${ }^{1}$.

\section{ILLNESS AS A CONCEPT}

It is assumed that illness may be regarded as a mental category subject to verbalization using appropriate language and/or non-linguistic symbolization ${ }^{2}$. The notions of illness encoded in language manifest themselves in many different forms, i.e. not only in stable verbal constructions but also in behaviour, rituals or customs enshrined and established in and through tradition. A folk healing ritual, combining the word (speaking) and the action (doing), perpetuated many old opinions and judgements on the functioning of man, health and illness. Therefore, it is assumed that such rituals, which appear as a set of ideas, beliefs, certain verbal and non-verbal behaviour, can be analysed applying the principles adopted in the reconstruction of the linguistic view of the world ${ }^{3}$. Linguistic and cultural view of the world is understood as a common interpretation of reality, which may be explained through both verbal and non-verbal data preserved in established cultural texts ${ }^{4}$. This assumption allows for better concentration on customs, rituals, beliefs and ceremonial props, i.e. on the context in which linguistic data is properly decoded. Such an approach is also associated with the assumption postulated much earlier by N.L. Tołstoj and J. Bartmiński ${ }^{5}$ which took into account the so-called extra-linguistic knowledge, which in ethnolinguistic research is closely connected with a comprehensive use of ethnographic and folk materials in the reconstruction of the linguistic view of the

1 In the article I refer to the material included in the book by M. Marczewska, entitled Ja cię zamawiam, ja cię wypędzam... Choroba. Studium językowo-kulturowe, Kielce 2012.

2 K. Zamiara, Kulturowy wymiar kategorii choroby, [in:] Zdrowie i choroba. Problemy teorii, diagnozy i praktyki, red. J.M. Brzeziński, L. Cierpiałkowska, Gdańsk 2008.

3 Cf. e.g. J. Bartmiński, Pojęcie językowego obrazu świata $i$ sposoby jego operacjonalizacji, [in:] Jaka antropologia literatury jest dzisiaj możliwa?, red. P. Czapliński, A. Legeżyńska, M. Telicki, Poznań 2010, pp. 155-178.

4 Cf. e.g. M. Fleischer, Obraz świata. Ujęcie z punktu widzenia teorii systemów i konstruktywizmu, „Język a Kultura” 2000, nr 13, pp. 45-71.

5 Cf. e.g. N.L. Tołstoj, Język a kultura (niektóre zagadnienia słowiańskiej etnolingwistyki), „Etnolingwistyka” 1992, nr 5, pp. 15-25; J. Bartmiński, Nikita Iljicz Totstoj i program etnolingwistyki historycznej, „Etnolingwistyka” 1992, nr 5, pp. 7-13; idem, Językowe podstawy obrazu świata, Lublin 2006, p. 14. 
world ${ }^{6}$. The postulate of extending the material base appears in ethnolinguistic works on a regular basis ${ }^{7}$. The importance of 'with-linguistic' data is also stressed by S. Niebrzegowska-Bartmińska, pointing to the relevance of taking into account iconic imagery, negative, zeroed data, which construct the Polish map of oblivion or covert memory ${ }^{8}$ in the reconstruction of the linguistic view of the world.

\section{ILLNESS LEXICOGRAPHIC DEFINITIONS}

As it is commonly understood, health is a condition in which the body functions properly, i.e. according to the norm, and with the absence of illness. Illness, in turn, is an abnormal functioning of the body (not compliant with the norm, see euphemistic: mieć ktopoty ze zdrowiem [to have problems with health] "to be ill"; nie być zdrowym [not to be healthy] "to be ill"; z czyimś zdrowiem nie jest najlepiej [one's health is not good] "one is ill", also: powrót do zdrowia, wracać do $z$ drowia [to get well soon, to recover] - i.e. to return to normal), simply the lack of health. In the Polish language dictionaries, illness is defined as 'a pathological process manifested by an abnormal functioning of the body or its part' (fig. also as 'an abnormal condition, a defect, distortion, deviation from the accepted norms, laws, etc., vulnerability), which allows to define the most important feature of condition: its abnormality and uniqueness.

\section{ETYMOLOGICAL CONSIDERATIONS}

Several ways of looking at ILLNESS are manifested in etymology. According to etymological data, illness is: 1 . ugliness, 2 . leanness, dryness 3 . wretchedness, 4. evil, 5. impure forces, 6 . pain ${ }^{9}$. All ways of looking at illness are associated with

6 Tołstoj treated language as one of the interacting codes (apart from the ritual, mythological and objective ones), as a "verbal culture code and its creator", whereas the ritual was seen as a text expressed through the semiotic language of culture, in which several codes were distinguished, namely: verbal (words), objective (objects, items), actional (action), locative and temporal. Bartmiński also repeatedly stressed the need to take into account in the reconstruction the "adopted and prevailing, i.e. conventionalised, behaviours" that demonstrate socially embedded knowledge about the world, common to the sender and the receiver; the knowledge which is associated with convictions and beliefs. Cf. ibidem.

7 Cf. e.g. W. Chlebda, O źródtach, celach $i$ drogach postępowania etnolingwistycznego w badaniach porównawczych, „Studia Slavica. Slovanské Studie” 2010, nr 14, pp. 121-134.

8 S. Niebrzegowska-Bartmińska, Jakie dane sa relewantne etnolingwistycznie, „Etnolingwistyka" 2017, nr 29, pp. 16-19.

9 M. Stec, Konceptualizacja pojęcia choroba w polszczyźnie, „Poradnik Językowy” 2007, nr 1, pp. 20-32. 
the negative evaluation of the very phenomenon and are related to the patient's perspective (feeling pain, observation of one's body). Body-centrism (anthropocentrism, anthropomorphism, somatocentrism), characteristic of human thinking, makes the picture of illness established in language associated with a specific perception of the body (see: THE BODY AS MECHANISM/CONTAINER, THE BODY AS BATTLEFIELD) and includes the distinctive assessment of the very phenomenon. According to an observation of J. Puzynina "a value is not just what is thought and/or felt to be good but also what is thought and/or felt to be bad. However, the latter is rather rarely used. More frequently we speak about values as about something which is considered to be good"10. Illness is, therefore, a negative value, anti-value, adversity experienced by man.

\section{ILLNESS ON THE BASIS OF THE LINGUISTIC DATA}

The analysis of a variety of language data leads to the conclusion that illness is the opposite of health as the most important (always positive) value. Since health is a whole, completeness, gaiety, being intact, strength, vigour, hardness, illness is a weakness, destruction, disintegration, the result of destruction, damage, deterioration (cf. zepsute zdrowie, opsuty (deteriorated health; deteriorated) 'a person inflicted with illness through eating and made talk nonsense'). The complete, intact body was not only the supreme good but also a guarantor of proper functioning in the community. Therefore, the most important goal of folk treatment was to get rid of the danger and restore the state of completeness and fullness. Illness constituted a threat to the well-being of an individual and society and as such was considered to be a dangerous state, evil with which one had to fight using various means.

\section{METAPHORS OF ILLNESS}

A metaphorical approach to illness and viewing it as an opponent or war/ fight is typical of our thinking. The dictionary definition of fight as 'an action which aims to remove, destroy, dispose of or overcome something' indirectly indicates the mechanism of thinking about illness. It is something wrong that must be removed, disposed of, overcome, fought [in Polish: usunać, pozbyć się, przezwycięzyć, zwalczyć] in order to return to the state of balance (health). S. Sontag wrote that among all the metaphors of illness, the military ones (attack,

10 J. Puzynina, Człowiek - język - wartość, [in:] eadem, Stowo - wartość - kultura, Lublin 1997, pp. 249-261. 
war, enemy) seem the most catchy. Consequently, illness is an external phenomenon, an alien element/thing in our body, an invader ${ }^{11}$. Since 'the essence of metaphor is to understand and experience a certain kind of thing in terms of another thing"12 it is not surprising that illness, always dangerous as it eliminates man from normal life, is treated as an enemy with whom we need to fight using specific tactics/strategies in order to overcome the condition and win the battle. Analysing the metaphors of illness we observe that the fight takes place against a specific ailment - enemy ('ILLNESS IS AN ENEMY'); healers and doctors are soldiers, magic spells, procedures and sorcery as well as a variety of natural remedies, amulets, etc. are weapons, the body is a battlefield and combating disease (recovery) is a victory in this specific war.

\section{ILLNESS AS A CONSCIOUS BEING}

Illness exhibits a remarkable activity. It is, in fact, aggressive in relation to man. We speak of zagrożeniu choroba, niebezpieczeństwie choroby, jej ataku, wybuchu, inwazji (inwazyjnym raku), o naszej obronie, obronie organizmu, walce $z$ choroba, zwalczaniu choroby, zmaganiu się z choroba, przesileniu, zwyciestwie $z$ choroba, poddaniu sie chorobie [the risk of illness, its attack, outbreak, invasion (invasive cancer), our defence, the defence of the body, combating and fighting illness, breakthrough, the victory over illness, surrendering to it], etc. Illness attacks us, touches us, eats us or ruins us [in Polish: atakuje nas, dotyka, wręcz toczy, rujnuje]. An extraordinary activity which is attributed to illness makes a person a passive recipient of its actions, see: illness beats somebody, seizes somebody, forces its way through somebody (when a person is sneezing), fights, breaks, grips, tires, kills, haunts somebody, sits on somebody, drags, sits somewhere (e.g. in a shirt), knocks somebody down, crashes somebody and strikes somebody ${ }^{13}$ [in Polish: choroba bije kogoś, bierze kogoś, przedziera się, ttucze kogoś, tamie kogoś, chwyta/pochwyca, męczy, morduje, nawiedza człowieka, przysiada człowieka, rozwleka się, siedzi (np. w koszuli), złoży/składa, powala człowieka, zwala człowieka/ścina $z$ nóg, zwija człowieka]. Less often man catches illness, grabs it or even inhales it. The terms used for illness are also interesting: stabość, dolegliwość, chorość, cierpienie, ból, boleść, schorzenie, zaburzenie, zwyrodnienie,

11 S. Sontag, Choroba jako metafora. AIDS i jego metafory, Warszawa 1997 (the first essay: pp. 5-90).

12 G. Lakoff, M. Johnson, Metafory w naszym życiu, Warszawa 1988, p. 27.

13 Cf. e.g. S. Spittal, Lecznictwo ludowe w Załoźcach i okolicy, „Rocznik Podolski” 1938, nr 1, pp. 68-69. 
niezdrowie, niedomaganie, niedyspozycja, bolaczka, problem, utrapienie, udręka, wada, gościec/gość [weakness, discomfort, suffering, pain, sorrow, illness, disorder, degeneration, condition, indisposition, vulnerability, problem, affliction, anguish, defect, rheumatism/guest]. The last term is characteristic as etymological information connected with the word gość [guest] presents a distinctive way of thinking about illness itself ('a person visiting a house or entertained there, Old Polish: przybysz, obcy, cudzoziemiec 'visitor, alien, foreigner'; proto-Slavic: gostb 'newcomer, alien, a person offered hospitality, a guest', Gothic: gasts 'alien, foreigner'; Latin: hostis originally 'alien, guest' later 'enemy, foe'; from ProtoIndo-European: "ghostis 'newcomer, alien'; on the one hand, somebody desired, on the other, 'undesired newcomer, enemy'; gościec [rheumatism] derives from the above; Czech: hostec - dialect 'rash, dandruff'; Slovak: hostec 'reumatism', dialect: 'lichen'; Ukrainian: hostéc 'reumatism' SłSEJP/I/328; BorSEJP/174). It is also worth referring to the etymology of the word wróg [enemy]. In the $14^{\text {th }}$ century, 'enemy, opponent', 'devil, deuce, Satan'; Russian: vorog 'enemy, opponent'; old-fashioned 'Satan, devil', dialect 'folk healer'; Old-Church Slavonic: vragz 'foe'; Croatian: vrâg 'devil, Satan, evil spirit'; Lithuanian: vargas 'poverty, misery, destitution, hardship'; vèrgas 'slave'; Latvian: vargs 'unhappy, ill, poor'; 'poverty, destitution'; vārgt 'be sick, deteriorate, be unhappy'; vęrgs 'slave', Gothic: wraks 'pursuer', wrikan 'haunt', Old English: wrecca 'exile', wrecan 'cast out', from Proto-Indo-European: "uerg 'crush, speed, race, stalk'. Presumably, the original meaning of the word referred to the 'one who chases or stalks; stalker' (BorSE/711). Etymological data confirms a specific reception of illness by man, observing its symptoms through the prism of his/her own body with regard to which illness was not only somebody/something alien, somebody/something that resides temporarily in the body, but also somebody/something dangerous, hostile or destructive. Folk people imagined illness in various forms: animal (e.g. as cattle plague) and human, demonic - as an evil spirit (MAAE 1910/11/293); pain residing in man: "Illness is imagined as 'pain' sitting inside the man, which has to be taken out and killed by means of either an 'order' or 'burning"' (MAAE 1914/13/70); cf. also: "The meaning of the term Gościec [rheumatism] is incomparably more extensive than in the medical science, where it is simply the Polish term for rheumatism. It is an embodiment of illness residing in each person as if being an invisible guest who, in the case of an improper behaviour of man, manifests itself in different ways" (Lud 1897/3/254). "Gościec - commonly known as plica Polonica - is not only a chronic disease but also a supernatural being that moves from place to place, makes noise, is very sensitive and takes revenge on the man. In short, it is a mysterious and mystical being" (BiegLecz/259). "Gościec is very choosy and no one knows what it is comfortable with" (Lud 1897/3/254). 
J.Burszta pointed out that among Slavs "there was a common belief that every illness is not the result of malfunctioning of the body, which could live forever, but of something external that enters into man due to [...] evil powers; therefore, illness is some kind of a personalised entity (imagined in different ways) which, by means of appropriate treatment, can be expelled, transferred to the elements - wind, water, stones, fire, or driven into another man"14. S. Spittal referred to illness as an enemy sent from the outside, see: "[...] as a folk concept, illness is an enemy lying in wait for the man's health, an enemy sent from the outside, from a different world [...]. This concept of illness as an alien, evil spirit is illustrated most clearly by numerous folk expressions: wlazła w niego choroba, jak zmęczony oraniem położyt się $i$ usnat; jak napit się wody do smaku; jak go zawiato, owiato; teraz choroba chodzi po wsi, choroba chodzi po ludziach, a nie po lesie; ztapała go choroba, chwyciła go choroba; choroba mordowała go, ttukta; trzesto go, mrozito, jeść mu nie dawało; lekarstwo tak zbrzydzito chorobę, że wyszła z niego, opuścita go; mocowat się z choroba, bo silny chtop, ale go tak $i z$ nóg zwaliła; obsypało go krostami; bodajby cię choroba wzięta; bodajby cię szlag trafil; choroba gada przez chorego [illness entered him as he lay down tired after a hard day ploughing; he drank some water to get the taste of it; he was blown by the wind; now illness is walking around the village; illness just happens to people not to forests; illness grabbed him; murdered him, hit him; made him feel cold; starved him; the cure made illness feel so disgusted that it left him, came out of him; he wrestled with illness as he is a strong man but it took him down; illness covered him with rash; God damn you; drop dead; illness speaks through the sick]. There was always something that crawled into the sick and performed different tricks. For this reason, illness could be scared away, injured or hurt, buried or vaccinated or, indulging it, it could be appeased and forced to leave the sick"15.

\section{TREATMENT}

Thinking about illness which acts, experiences and behaves like man translates into a specific motivation of treatment attempts (and into the expressions used in such a treatment, including: skadeś przista - wracaj ${ }^{16}$ [go back where you are from], cf. justification of fasting in the case of epilepsy: "One can get rid of an

14 J. Burszta, Lecznictwo ludowe, [in:] Kultura ludowa Wielkopolski, red. J. Burszta, t. 3, Poznań 1967, p. 394.

15 S. Spittal, op. cit., pp. 68-69.

16 D. Tylkowa, Medycyna ludowa w kulturze wsi Karpat Polskich, Wrocław-WarszawaKraków-Gdańsk-Łódź 1989, p. 68. 
illness like this through fasting and eating only dairy products on Easter Sunday for three consecutive years. Then, starved and offended, the illness will go away"17. Treating illness as a conscious being is associated with the procedures used: insulting, pleading, scolding, casting out, curbing, etc. "Illness is, therefore, driven out or asked to leave a human body just like an evil spirit. The treatment procedure among our people is similar to the one used by other peoples in primitive times demonstrating outstanding traces of it. It resorts to the same combat resources, whether in the case of defense or attack, that were used by our ancestors in ancient times. We know scolding and name-calling of illness, casting out and frightening, asking out and indulging illness or cheating those invisible spirits by means of pleasant treatment. The result of it - the relics of pagan beliefs - include bloodless sacrifices, votive offerings in the form of rags and garments, fasting, prayers and phlebotomy as a substitute of proper bloody sacrifice" ${ }^{18}$. The actions attributed to illness, its harmfulness as well as enormous fear of it, are reflected in numerous diverse practices that were applied to overcome illness, destroy it, cast it away from a man. Various treatments undertaken by peasants point to a specific, material

17 S. Spittal, op. cit., p. 150. Adolf Czerny wrote about folk perceptions of illness in a similar way, pointing to a close link between those perceptions and the treatment methods applied: "[...] a folk doctor tried to cast the evil spirit out of the body, in which it resided, or to remove alien things that entered into the body as a result of anger of hostile or evil people (sorcerers). Various methods were used to cast the evil spirit out of the body". Czerny mentions asking pure deities (including the sun) for help in getting rid of illness: "Some traces of this custom are found among Christians, who turn to praying to some patron saints: saints have replaced pure pagan spirits (deities). An episode from the saint's life, or some detail in his/her image, or difficulties in understanding his/her name became the reason for establishing patrons of certain illnesses. Finally, the primitive man would get rid of illness under false pretences - namely trying to cast the evil spirit out of the human body and into the body of an animal or into a tree. Numerous traces of this belief are found among all peoples of Europe, either in ordered ways of treating illness or other methods of folk medicine and belief in a variety of creatures causing illness". Among Slavic peoples, the belief in the spirits of illness is best preserved among Russians and Slavs from the south. Cf. A. Czerny, Istoty mityczne Serbów Łużyckich, „Wisła” 1985, nr 9, pp. 697-698. This characteristic thinking about illnesses is common to many culture circles, e.g. in a shamanic vison of the world, some basic causes of illness were distinguished. They were caused by spirits kidnapping the human soul into the afterlife, placing objects in the body of the sick by spirits or evil sorcerers and breaking the taboo, i.e. acting against the norms applicable in a given community (this was also a threat to the whole community). Cf. P. Vitebsky, Szaman, Warszawa 1996. Therefore, there are certain universal judgements regarding the origin of illness, shapes assumed by it, ways of casting illness out of the human body, etc. The illness's entering and leaving the body is also recorded in some statements, e.g. U ciebie to [ta choroba] było w środku i teraz wyszło na wierzch [The illness was inside you and now it came out]. Cf. A. Wilczkowski, Medycyna ludowa. Między tradycja a wspótczesnościa, [in:] Centrum na peryferiach. Monografia społeczności lokalnej Ejszyszek i okolic na Wileńszczyźnie, red. A. Perzanowski, Warszawa 2005, p. 221.

18 S. Spittal, op. cit., p. 73. 
thinking about illness. The treatments include, e.g.: 1. przygwożdzenie choroby [nailing illness down] (in fact a sign or symbol of it: hair, a small part of a fingernail, fibers from the patient's clothes) in a remote, enclosed place, usually by means of a nail, pin, wedge, etc.; 2. przeszczepienie/zaszczepienie choroby [transplantation of illness] onto a tree, living creature, animal or man, 3. zakopanie [burying] illness, isolated in the form of hair, fingernails or secretions: urine, feces or sputum, in a place which is difficult to reach; 4 . sptawianie [floating] illness by throwing a part of garment, for instance, into tap water; 5 . spalenie [burning] in a furnace; 6 . wyrzucanie/odrzucenie [casting out/rejecting] it (in the form of cloths) by throwing it above one's head and moving away from this place as fast as possible without looking back; 7. sprzedanie [selling] illness to another person; 8 nahodowanie [breeding] illness (transferring it onto bread and giving it to a dog to eat); 9. przemierzenie [overcoming] illness (especially in children); 10. wyliczenie/odliczenie [counting/deduction] of illness, especially counting backwards from 13 or 9 to 0 ; 11. przenoszenie [transferring] illness onto other items; 12. oplucie [spitting on] it or on a person that caused it; 13: zlizywanie [licking off]; 14. zmywanie [washing] illness with water; 15. okadzanie/okurzenie [smudging] (with hair, parts of clothes, fingernails, animal fur, herbs, etc.); 16. wiazanie [tying] it (with a ribbon or a thread), e.g. a red ribbon; 17. przewlekanie [threading] it through a narrow hole; 18. zawieszanie [hanging] illness (e.g. as a shirt) on a tree/cross or placing it under a stone, root, etc.; 19. modlenie się [praying]; zaklęcie [charming] illness by friends or acquaintances; 21. zastraszanie [intimidating] it; 22. dogodzenie [indulging] it; 23. obrzydzenie choroby [making illness disgusting]; 24. opisanie [describing] illness (with holy chalk, a hone, a comb or a knife); 25. wyssanie [sucking out] illness (while hurt or stung); 26. wykropienie (sprinkling) illness (with holy water) ${ }^{19}$. Thinking about illness in terms of a guest, a stranger or an enemy requires a specific action and therefore assumes performing a proper ritual, combining words and gestures ${ }^{20}$. M. Federowski wrote that "according to what is assumed by the folk, the power of words is so huge that it can cure even the most severe illness or, on the contrary, it can instantly bring death. It can turn a person into a stone or a bird or even a creeping reptile; it can ward off evil spirits and great plagues; in short, if a man only knows how and when to use words he is able to achieve all

\footnotetext{
19 Ibidem, p. 71, 86-90.

20 Information on acting by means of words is included in Oskar Kolberg's (1857-1890) collection. The examples of magic healing spells were also presented in "Lud", "Materiały Antropologiczno-Archeologiczne i Etnograficzne”, “Wisła”, “Zbiór Wiadomości do Antropologii Krajowej”. Disputes about folk spells were recorded by priest Władysław Siarkowski, who collected numerous formulas from the Świętokrzyskie region (Materyjały do etnografii ludu polskiego z okolic Kielc i Pińczowa; published in 1878-1879, 1880 and 1884).
} 
of the above. Sorcerers and fortune-tellers know how to pronounce words and what to do so as to make the words effective"21. In ethnolinguistic works ${ }^{22}$ magic healing formula called zamówienie is usually defined as a text, verbal expressions analogous to a magic ritual. As a magic expression ${ }^{23}$ it is closely related to a folk healing ritual, i.e. to the performance of certain actions - a magic formula is not only a text suspended in a given coding-decoding situation but also a product of a given community, its culture, customs, value systems, etc. It is a text distinguished by semantic, syntactic and lexical stabilization and its repetitive nature is connected with transmitting the whole added, global sense associated with the activation of old ideas about the world fixed in it. From the ethnolinguistic point of view, a magic healing formula is a text which is a manifestation of the mentality of a certain community, which results in specific information about the conceptualization of reality and the world view specific to the community.

\section{RITUAL SPEECH ACTS}

Seeing the likeness of illness to a CONSCIOUS BEING is connected with certain communicative strategies implemented in a healing ritual ${ }^{24}$. This is testified by conversations with illness included in the formulas, which can convince, scare, praise, etc. illness, i.e. affect it by words, e.g.: Chorobo, wyjdź z oka a idź do głowy, z głowy do ręki, z ręki do nogi, z nogi wejdź do ziemi [Illness - go out of the

21 M. Federowski, Lud okolic Żarek, Siewierza i Pilicy. Jego zwyczaje, sposób życia, obrzędy, podania, gusła, zabobony, pieśni, zabawy, przystowia, zagadki i właściwości mowy, t. 2, Warszawa 1889 , pp. 246-247.

22 Cf. e.g. S. Tolstoj's entry: Zagovory, [in:] Slavjanskije drevnosti. Etnolingvisticzeskij slovar', red. N.I. Tolstogo, Moskva 1999, pp. 239-244; S. Niebrzegowska-Bartmińska, Wzorce tekstów ustnych w perspektywie etnolingwistycznej, Lublin 2007; J. Rybarczyk-Dyjewska, Język jako narzędzie magii na przyktadzie zaklęć rosyjskich, Kraków 2013.

23 Magic expressions, including healing formulas, undoubtedly belong to ritual speech acts; they are complemented by reciting or declaring certain changes in the reality, e.g. that illness will be destroyed, neutralized, sent away into distant space. Naming spells and healing formulas of specific character - the terms used include "devilish", "black", "rotten", "rotten prayer" (which indicates the relation between people casting spells and evil forces). At times, they are referred to as kryjaki - secret texts.

24 Cf. also comments on understanding illness in Jewish culture: "Pre-modern cultures perceived illnesses as separate beings, whose existence was closely associated with that of the man, or as outsiders, creatures haunting the man and manifesting themselves in a certain condition (pain, stinging, swelling, redness, etc.). Some of them existed in a completely natural way in the body of their host. They were inherent and indispensable for proper functioning. Others were perceived as malicious intruders with whom man had to struggle (ranglen sich) until they were beaten ( $b a-$ jkumen) or until the man fell victim to them (faln a korbn). Cf. M. Tuszewicki, Żaba pod jezykiem. Medycyna ludowa Żydów aszkenazyjskich przełomu XIX i XX wieku, Kraków-Budapeszt 2015, p. 255. 
eye and go into the head, from the head to the arm, from the arm to the leg, from the leg (here a knife is put into the ground) to the ground [...] MAAE1904/7/81. Zamawiam cię / I wyganiam cię, zły bólu: / Z głowy, / Z mózgu, / Z uszów / I z ust, / I z brody / Uciekaj na morskie wody! Z piersi / I spod serca, i I ze wszystkich wnętrzności / Nie miej w tym chorym żadnej osiadtości! / Z rąk, / Z nóg / I z pięty / Uciekaj, ty bólu przeklęty! Tam gdzie słońce nie dogrzeje, i Gdzie wiatr nie dowieje, i Gdzie kogut nie dopieje, / Gdzie pies nie doszczeka, / Niech tam ból ucieka! / Na bory, / Na lasy, / Na suche korzenie, / Żeby cię nie znato żadne ludzkie plemię? ${ }^{\text {I5 }}$ [I enchant you / I cast you out, evil pain: / out of the head / out of the brain / out of the ears / and out of the mouth / and out of the chin / Run into the sea waters! Run away from the breast / and from underneath the heart / and from all innards / Do not settle into the sick! / I cast you out of the hands / the legs / the heel / Run away, you evil pain! Run where the sun does not shine / where wind does not blow / where a rooster does not crow / where a dog does not bark / Let the pain run there! / into the forests / into the woods / into the dry roots / so that it is never to be found by any human tribe!].

The following behavioural strategies, which show human responses to illness, are included in the ritual magic formulas ${ }^{26}: 1$. commands (addressed to illness), often expressed through the use of a verb and imperative meaning 'go away, go out', 'die, disappear', e.g. Różo, różyco, Kottunie, kołtunico, Wyleź z gtowy! [Rose, little rose, Boor! Leave the head!; 2. prohibition s closely connected with commands (addressed to illness in order to force it to stop its actions, e.g. Nie chodźże tam strzelcu-postrzelcu! [Do not go there, you nut!], 3. direct or indirect requests (addressed at illness or saints, who play the role of intermediaries and are beings whose power may enhance the request), e.g. Proszę cię tuszczko, żebyś oku nie szkodzita, Po źrenicy nie chodzita [Pannus, I urge you not to harm the eye, not to wander across the pupil]; 4. flatter $\mathrm{y}^{27}$ (taming, positive valuation of

25 F. Kotula, Znaki przeszłości, Warszawa 1976, p. 338.

26 S. Niebrzegowska-Bartmińska, Wzorce tekstów ustnych..., pp. 161-166. Cf. M. Marczewska, op. cit., pp. 290-291.

27 The broadly understood act of positive evaluation of the partner (a complement), considered as a means of exerting influence, is included into various communicative strategies, which aim at triggering the positive perlocutionary effect. The magic healing formulas use the so-called "manipulative variety of the complementary act", or flattery, which belongs to the techniques consisting in "exerting influence on another person in order to increase the attractiveness of the subject's features". However, it violates the principle of mutual assistance of partners in order to "preserve face". The intention of the ingratiator is in fact the desire to get more than is given to the interaction partner. Flattery wins over physical strength, being itself the strength that in a very subtle way, more subtle than a threat or order, presses on the receiver, gently and ingratiatingly forcing certain attitudes and behaviour". Cf. B. Drabik, Komplement i komplementowanie jako 
illness or saints, using diminutives), O mój bólu, o mój piękny, mój najpiękniejszy, mój najśliczniejszy...; Postrzale, / Postrzale mój kochany, / Proszę cię, / Nie rób w moim ciele rany; Mój postrzale śliczny, Badź mi okoliczny! [Oh, my pain, my beautiful, my most beautiful, most precious... / My gunshot / My beloved gunshot / Please / Do not hurt my body; My beautiful gunshot!]; 5. ap ologizing (to illness), e.g. Nie róbże mi rany, Bądź upamiętany! Nie psujże mi ciała! Przepraszam cię sama. [Do not hurt me, Come to your senses! Do not hurt my body! I apologize to you. 6 . frightening illness ${ }^{28}$, recalling more powerful forces which can eliminate it, e.g. Zesłat Pan Jezus świętego Franciska z ostrym miecem, ażeby porąbat, posiekał, żeby się nie serzyta, żeby kostecków nie tomała [Jesus gave us Saint Francis with a sharp sword to chop up the illness so that it does not spread and break our bones]; 7. giving advice, persuasion (persuading the disease to undertake a certain action; showing one's own example) e.g. Dokqd to idziesz żabo, żabulinko? / Nie chodź tam, bom ja tam byta. / Przeżegnałam cie raczka Najświętszej Panny / Wimię Ojca [Frog, little frog, where are you going? I Do not go there because I have been there already / I made a cross with the help of Virgin Mary / In the name of the Father], etc.; 8. threatening (with another element of the world which somehow mediates between the man/animal and the illness), e.g.: Dotad cię będę męcyt oście - Dopokad nie wyjda z mojéj krowy goście; skuła (wrzód w kopycie) Kéj ty idziesz skuła? Na bajory (moczary), na korzenie, kéj nie dochodzi stońce ani żadne stworzenie; na skóry toczyć, próć. A to ja ciebie w teb, a ty się wróć. [How long will I torment you, thistle? Until the guests leave the head of my cow; skuta (ulcer in the hoof) Ulcer, where are you going? To the marshes, to the roots where no sun and animals wander, to afflict the skin. I will grab you by your head and you will turn back].

Without a doubt, magic phrases are ritual speech acts: they become complete in a certain executive situation by reciting, undertaking certain actions, declaring specific changes to the reality, e.g. that illness will be destroyed, neutralized or sent into the distant space. This kind of declaration takes place without any visual interaction with a proper recipient of the phrase, namely illness. Instead, certain dramatic, theatrical effects are used, which means that rituals often turn into extremely complex performances, in which influencing illness goes beyond

akt mowy i komunikacyjna strategia, Kraków 2004, p. 19, 26-27, 32). It is worth remembering that flattery is also included in the list of types of behaviour that can disrupt the communication process. It could be the reason why it is appropriately limited in the analysed texts and "higher instance" is called upon just in case to defend the person falsely flattering illness.

28 Often the intention of frightening is hidden and consists of warning illness against the most powerful force, cf. Urok nie urok, / Przybywa sam Bóg / Od nieba do ziemie - Boskie przemienienie [regardless of any spell / God himself comes / From heaven to earth - divine transfiguration]. 
a verbal action: casting out the ailment (idź ode mnie, ustępuj [leave me, give in]), prohibitions directed at illness indirectly revealing the actions of the illness itself (abyś mnie nie trapit, nie naśladowat [so that you do not afflict me nor imitate me]), reciting prayers to saints (including the patron saint of the sick) and also numerous symbolic activities: pouring water, crossing oneself (making the sign of a cross over water, oneself, plica Polonica), dragging illness out into a distant space, etc. Performed actions were connected with particular ailments, e.g. reversing curses required the following actions and words: "Wimię Ducha Świętego / I Syna, / I Ojca. [In the name of the Holy Spirit / the Son / and the Father] followed by: Moje uroki! / Wszelkie przeskoki. Wiatrem? / Czy słońcem? / Czy ludzkiem okiem? / Ustapcie ode mnie, Józka! (albo inne). / Odejdźcie mie ze wszystkiem, / Niechaj będę spokojny, / Wimię Jezusa oddaje... (imię człowieka lub bydlęcia) / A Ty, Jezu, pomóż mi w każdej chwili, / Pomóż mi w minucie, / W chwili - / Bo ja Ciebie błagam / I błagać Cię będę do śmierci, / Do śmierci o Tobie pamiętać będę. [My curses! / With the help of wind / and the sun / and the human eye / Leave me / Leave me taking everything with you / Let me be calm / In the name of Jesus - I give ... (the name of a man or an animal) to you/ And, you, Jesus, help me in every moment / Help me in this very moment / Because I beg / I will beg you until my death / Until my death I will remember about you]. Then, there was the sign of a cross, saying the following words in the reverse order: W imie Ducha Świętego / I Syna / I Ojca. / Spale wegle nad toba / I uciekaj od... (imię) / Spokojny osoby, / Odsyń sie wietrze, / Odsyń sie słońce, / Odsyń się wszystko! / Ocyść powietrze, / Zrób jak najcyściejsze, / A mnie opuść z tego! [In the name of the Holy Spirit / and the Son / and the father / I will burn some coal over you / Leave! / Wind - leave! / Sun leave! / Everything - leave! / Clear the air / Make it the purest / Leave me!]. Finally, one had to make the sign of a cross - again in the reverse order. After the ritual is over, a glass of clean water is drawn from a well [...] making sure not to waste even a single drop of it [...]. A sign of the cross is made over it saying the words: In the name of the Father and of the Son, and the Holy Spirit. Amen! and then nine embers are placed in the glass. When they are all in water, I take them to the man or the animal, put two fingers into the water, the index finger and the middle finger, and then rub them against the head, starting from the forehead or against the animals' back - from the head up to the tail - spitting three times. Then I go outside to pour the water over the roof! Over a hut, if it is a man, or over a stable or pigsty, if it is an animal. And then it is over. Both the man and the animal are calmed down and the pain leaves them"29.

\footnotetext{
29 F. Kotula, op.cit., pp. 319-321.
} 


\section{CONCLUSIONS}

All performed verbal and non-verbal actions serve one overarching intention: the eradication, or casting illness out of the body. The intention is realized by means of a complex ritual, in which the word is reinforced with the appropriate gesture expression, performing symbolic actions which reveal the thinking of illness as an external factor and the possibility of getting rid of problems through formulating some orders given to illness as well as through prayers to saints and physical separation of illness from the sick (from the inside of the body towards the outside of it) and placing it in an alien space (in which illnesses reside). A medicinal ritual is undoubtedly an entirety and its impact on the patient and illness is based on the use of effective (in the opinion of the treated person and the healer) verbal and non-verbal acts. The magic formulas record information about various actions undertaken by the man against illness.

In a very specific existential situation, which is illness, the most basic mechanisms of thinking about the reality are revealed. Hence a healing ritual shows perceptions and judgements referring to illness, based on one's own body experiences, pain and weakness. These judgements may be observed through specific materialization obtained through language manifested in a specific executive situation. The analysis of linguistic data allows for discovering the significance of performed actions in the process of magical healing, as these actions complement words and are strongly connected with beliefs about illness in general. They form a specific testimony of the man's struggle with illness.

According to J. Burszta, the entire "folk medicine has grown somehow organically from the body of changeable folk beliefs, customs and habits, from the folk world view, from thinking and practical actions aiming at providing people with the most precious good which is health" ${ }^{30}$. The treatment consisted of implementing a specific plan to combat illness, i.e. gradually taking it out of the body and forcing the guest to leave the patient's body. The human condition of the sick is an experience "demanding its ritual solution" using the language and the gesture. It is an experience translated into the need for magic in which rituals, together with the causative word, play a significant role. A characteristic disease animization or anthropomorphism is an attempt to tame a situation in which man does not feel safe. It is also associated with the original demonic nature of illness that plagued the human body. Apparently, the magic healing formulas perpetuated the old way of thinking about illness and a great hope that since illnesses entered the body from the outside it was possible to cast them

\footnotetext{
30 J. Burszta, op. cit., p. 429.
} 
out. It was necessary, however, to be able to show them the way and convince them to leave the body.

Abbreviations used:

BiegLecz H. Biegeleisen, Lecznictwo ludu polskiego, Kraków 1929.

BorSEJP W. Boryś, Stownik etymologiczny języka polskiego, Kraków 2005. „Lud. Organ Polskiego Towarzystwa Etnologicznego”, issued by Polskie Towa-

Lud rzystwo Ludoznawcze we Lwowie, Lwów-Warszawa-Kraków-Poznań-Wilno 1895-1937.

„Materiały Antropologiczno-Archeologiczne i Etnograficzne” issued through

MAAE the efforts of Komisja Antropologiczna Akademii Umiejętności w Krakowie, vol. 1-14, Kraków 1896-1919.

SłSEJP F. Sławski, Słownik etymologiczny języka polskiego, vol. 1-5, Kraków 1952-1982.

\section{REFERENCES}

Bartmiński J., Językowe podstawy obrazu świata, Lublin 2006.

Bartmiński J., Nikita Iljicz Totstoj i program etnolingwistyki historycznej, „Etnolingwistyka” 1992, nr 5.

Bartmiński J., Pojęcie językowego obrazu świata i sposoby jego operacjonalizacji, [in:] Jaka antropologia literatury jest dzisiaj możliwa?, red. P. Czapliński, A. Legeżyńska, M. Telicki, Poznań 2010.

Burszta J., Lecznictwo ludowe, [in:] Kultura ludowa Wielkopolski, red. J. Burszta, t. 3, Poznań 1967.

Chlebda W., O źródłach, celach i drogach postępowania etnolingwistycznego w badaniach porównawczych, „Studia Slavica. Slovanské Studie” 2010, nr 14.

Czerny A., Istoty mityczne Serbów Łużyckich, „Wisła” 1985, nr 9.

Drabik B., Komplement $i$ komplementowanie jako akt mowy i komunikacyjna strategia, Kraków 2004.

Federowski M., Lud okolic Żarek, Siewierza i Pilicy. Jego zwyczaje, sposób życia, obrzędy, podania, gusła, zabobony, pieśni, zabawy, przysłowia, zagadki i właściwości mowy, t. 2, Warszawa 1889.

Fleischer M., Obraz świata. Ujęcie z punktu widzenia teorii systemów i konstruktywizmu, „Język a Kultura” 2000, nr 13.

Kotula F., Znaki przeszłości, Warszawa 1976.

Lakoff G., Johnson M., Metafory w naszym życiu, Warszawa 1988.

Marczewska M., Ja cię zamawiam, ja cię wypędzam... Choroba. Studium językowo-kulturowe, Kielce 2012.

Niebrzegowska-Bartmińska S., Jakie dane sq relewantne etnolingwistycznie, „Etnolingwistyka" 2017, nr 29. 
Niebrzegowska-Bartmińska S., Wzorce tekstów ustnych w perspektywie etnolingwistycz$n e j$, Lublin 2007.

Puzynina J., Człowiek - jezzyk - wartość, [in:] eadem, Stowo - wartość - kultura, Lublin 1997.

Rybarczyk-Dyjewska J., Język jako narzędzie magii na przykładzie zaklęć rosyjskich, Kraków 2013.

Sontag S., Choroba jako metafora. AIDS i jego metafory, Warszawa 1997.

Spittal S., Lecznictwo ludowe w Załoźcach i okolicy, „Rocznik Podolski” 1938, nr 1.

Stec M., Konceptualizacja pojęcia choroba w polszczyźnie, „Poradnik Językowy” 2007, nr 1.

Tołstoj N.I., Język a kultura (niektóre zagadnienia słowiańskiej etnolingwistyki), „Etnolingwistyka” 1992, nr 5.

Tołstoj S., Zagovory, [in:] Slavjanskije drevnosti. Etnolingvisticzeskij slovar', red. N.I. Tolstogo, Moskva 1999.

Tuszewicki M., Żaba pod językiem. Medycyna ludowa Żydów aszkenazyjskich przełomu XIX i XX wieku, Kraków-Budapeszt 2015.

Tylkowa D., Medycyna ludowa w kulturze wsi Karpat Polskich, Wrocław-WarszawaKraków-Gdańsk-Łódź 1989.

Vitebsky P., Szaman, Warszawa 1996.

Wilczkowski A., Medycyna ludowa. Między tradycją a wspótczesnością, [in:] Centrum na peryferiach. Monografia społeczności lokalnej Ejszyszek i okolic na Wileńszczyźnie, red. A. Perzanowski, Warszawa 2005.

Zamiara K., Kulturowy wymiar kategorii choroby, [in:] Zdrowie i choroba. Problemy teorii, diagnozy i praktyki, red. J.M. Brzeziński, L. Cierpiałkowska, Gdańsk 2008.

Streszczenie: W artykule omawiam utrwaloną w różnorodnych danych językowych relację, która dotyczy człowieka i choroby. Bazuję na materiale folklorowym, przywołuję przede wszystkim ludowe formuły magiczne, zwane zamówieniami. Magiczny rytuał leczniczy postrzegam jako całość, w której słowo współtowarzyszy określonym czynnościom, odbywającym się w wyznaczonym czasie, w wyznaczonym miejscu, przy zastosowaniu określonych atrybutów. W bardzo specyficznej sytuacji egzystencjalnej, jaką jest choroba, ujawniają się najbardziej elementarne mechanizmy myślenia o rzeczywistości, stąd też rytuał leczniczy ukazuje oparte na własnym doświadczaniu ciała wyobrażenia i sądy dotyczące choroby. Sądy te można obserwować dzięki swoistej materializacji, jaką uzyskują za pośrednictwem języka/tekstu objawiającego się w konkretnej sytuacji wykonawczej. Analiza danych językowych/tekstowych pozwala na odkrycie właściwego sensu czynności wykonywanych w procesie magicznego uzdrawiania; działania te stanowią dopełnienie słowa, są też silnie powiązane $\mathrm{z}$ wierzeniami na temat choroby $\mathrm{w}$ ogóle i stanowią charakterystyczne świadectwo walki człowieka z chorobą.

Słowa kluczowe: etnolingwistyka; językowy obraz świata; rytuał leczniczy; magia 